\title{
Comparison of the Independence Learning of Prospective Teacher through the Use of E-Learning during the Covid-19 Pandemic
}

\author{
Hermansyah $^{1}$, Eryuni Ramdhayani ${ }^{2}$, Nurhairunnisah $^{3}$, Erma Suryani ${ }^{*}$, Sri Sugiarto ${ }^{5}$ \\ 1 Physics Education Program, Universitas Samawa, Sumbawa, Indonesia. \\ ${ }^{2}$ Biology Education Program, Universitas Samawa, Sumbawa, Indonesia. \\ ${ }^{3}$ Education Technology Program, Universitas Samawa, Sumbawa, Indonesia. \\ ${ }^{4}$ Economic Education Program, Universitas Samawa, Sumbawa, Indonesia. \\ ${ }^{5}$ Indonesian language and literature education Program, Universitas Samawa, Sumbawa, Indonesia.
}

\section{DOI: $\underline{10.29303 / \text { jppipa.v7iSpecialIssue.1032 }}$}

\section{Article Info}

Received: October 12th 2021

Revised: November 23rd, 2021

Accepted: December 2nd, 2021

\begin{abstract}
The current learning process is carried out online with the help of e-learning. This certainly changes the pattern of learning and this pattern requires students to be more independent in the learning process. This study aims to compare the effect of using elearning on the learning independence of prospective teachers in the exact field of exact sciences with the social and humanities field at Universitas Samawa. Respondents in this study amounted to 62 students from five study programs under the auspices of the Faculty of Teacher Training and Education. Respondents were divided into two based on the specifications of the fields of science, exact sciences, and social humanities. The data collection technique used observation technique with the tool used in the form of a Likert scale questionnaire. The results showed that in general, student-teacher candidates in the field of social humanities obtained a higher score of learning independence than prospective students in the field of exact sciences, while based on each indicator of learning independence, prospective students in the field of exact sciences teachers were higher than prospective students in the field of social humanities specifically on disciplinary indicators. The results of the influence test show that the significant value is greater than 0.05 . So, it can be concluded that the use of e-learning during the covid-19 pandemic does not significantly affect the learning independence of prospective teacher students at Universitas Samawa.
\end{abstract}

Keywords: Independent learning; pre-service teacher; e-learning; covid-19

Citation: Hermansyah, H., Ramdhayani, E. ., Nurhairunnisah, N., Suryani, E. ., \& Sugiarto, S. . (2021). Comparison of the Independence Learning of Prospective Teacher through the Use of E-Learning during the Covid-19 Pandemic. Jurnal Penelitian Pendidikan IPA, 7(SpecialIssue), 151-157. https://doi.org/10.29303/jppipa.v7iSpecialIssue.1032

\section{Introduction}

Education systems around the world are facing difficult times due to the Covid-19 pandemic forcing universities to implement conventional learning through online learning (Tarhini et al., 2017). In Indonesia, the Government issued a policy to close schools and colleges to prevent the spread of the COVID-19 virus. Educators and students as important elements in learning are required to switch from faceto-face learning to online learning (W. Bao, 2020;
Basilaia \& Kvavadze, 2020). The development of information and communication technology today can support online learning. Online learning is experiencing rapid development (Haryadi \& Jannah, 2020). With the use of Information and Communication Technology (ICT), higher education has moved to online platforms to assist students and is adopting virtual teaching to deliver online courses (Ali, 2020; Hodges et al., 2020). The online platform is one of the learning media needed in learning. The use of learning media is an important factor that affects the 
achievement of learning objectives. So the learning media used must be adapted to the characteristics of the material being taught, or the learning model used (Yulianci et al., 2021). Online learning can support student learning independence because it can be accessed by lecturers and students anytime and anywhere (Kusmana, 2011; Rizal \& Walidain, 2019). Each student must have independent learning to be more active, such as finding learning resources independently or so on.

Learning independence is the willingness and initiative of students to carry out their own learning activities without the help of others and are responsible for solving learning problems (Herwanto et al., 2020; Lestari et al., 2019). This is in line with the opinion of Ahmad et al. (2019) that with independent study, students' learning responsibilities will increase as well as self-discipline. Learning independence is an internal factor found in students that can affect the learning process. Mukhlisa et al., (2021) state that learning independence is one of the factors that are considered to affect student achievement. Learning independence has other terms, namely independent learning, independent thinking, independent learning, selfefficacy, and self-esteem (Sumarmo, 2010). Independence is the ability to manage everything that is owned, namely knowing how to manage time, walk and think independently accompanied by the ability to make decisions in problem-solving (Nasution, 2018). One of the online platforms that can be used to support the learning independence of prospective teachers in learning during the COVID-19 period is e-learning. Crawford et al. (2020) stated that UNESCO also recommended that higher education institutions need to prepare online learning tools or e-learning. Elearning has emerged as a powerful learning medium, especially using internet technology as a way of delivery (Amin et al., 2021). This is a challenge for universities, especially educators (Fahmi, 2020), to be able to choose effective learning media to support online learning such as e-learning. E-learning is also called learning management that utilizes technology as a learning tool (Sulistyohati, 2020; Tigowati et al., 2017; Apriansyah \& Pujiastuti, 2020). E-learning is a learning platform that utilizes information and communication technology networks so that online learning activities occur. The American Society of Training and Education (ASTD) explains that E-learning is the application of digital media in the learning process such as internet media, computer networks, broadcast satellites, audio cassettes, video, interactive television, CD-Room, etc. (Mahdi \& Sally., 2010). E-learning is seen as having a major influence on students' academic performance
(Tawafak et al., 2020). In addition, the use of e-learning can increase student interaction with lecturers (Amin et al., 2021) and can help students independently understand the subject matter (Hernawati \& Aji, 2016). Likewise, the opinion of Naidu (2006) explains that the type of e-learning is individualized self-paced, meaning that students can learn and access their own learning resources via the internet. The e-learning system provides an opportunity for instructors/ faculties where they can manage, plan, deliver and track the teaching and learning process (Amin et al., 2021).

Based on the above, this study aims to compare student learning independence in the exact field with the social humanities field through e-learning during the covid-19 pandemic.

\section{Method}

This type of research is a qualitative descriptive method. The research subjects are prospective teachers from five study programs at the Faculty of Teacher Training and Sciences, namely Physics Education, Biology Education, Indonesian Language and Literature Education, Economics Education, and Educational Technology. The research sample is as many as 62 teacher candidates. The data collection instrument used was a Likert scale questionnaire with a scale of 1-5. A scale of 1 indicates strongly disagree, 2 indicates disagree, 3 indicates less agree, 4 indicates agree, and 5 indicates strongly agree. The learning independence questionnaire contains 20 statements that have been adjusted with indicators including selfconfidence, responsibility, initiative, and discipline according to Febriastuti (2013), as shown in Table 1 which is measured. Data analysis techniques were carried out by classifying data, tabulating data, scoring respondents' answers, processing the number of respondents' answer scores, calculating the percentage of questionnaire answers for each statement item, calculating the average percentage of the questionnaire, visualizing the data in the form of pictures, and interpreting the percentage of answers to the questionnaire as a whole. The data obtained in the qualitative form are then quantified using the following equation.

$N=\frac{\text { Total Score Obtained }}{\text { Maximum Score }} \times 100$

The final results obtained are interpreted into an interpretation scale, according to (Riduwan, 2012) as in Table 2. 
Table 1. Independent Learning Indicators and Aspects Assessed

\begin{tabular}{|c|c|c|}
\hline No. & Indicator & Rated Aspect \\
\hline \multirow[t]{3}{*}{1.} & Self-confident & Students learn not to depend on others. \\
\hline & & Students have the courage to act. \\
\hline & & Students believe in themselves. \\
\hline \multirow[t]{3}{*}{2.} & Responsibility & Students have self-awareness in learning. \\
\hline & & Students do all the assignments given by the lecturer. \\
\hline & & Students are active and serious in learning. \\
\hline \multirow[t]{3}{*}{3.} & Initiative & Students learn at their own pace. \\
\hline & & Students ask or answer without being asked by others. \\
\hline & & Students try to find other reference sources in learning without being asked by the lecturer. \\
\hline \multirow[t]{3}{*}{4.} & Discipline & Students pay attention to the lecturer's explanation when learning. \\
\hline & & Students do not delay the assignments given by the lecturer. \\
\hline & & Students are not lazy to study. \\
\hline
\end{tabular}

Table 2. Score Interpretation Criteria

\begin{tabular}{lll}
\hline No & Scale & Category \\
\hline 1 & $81-100$ & Very Hight \\
2 & $61-80$ & Hight \\
3 & $41-60$ & High enough \\
4 & $21-40$ & Low \\
5 & $0-20$ & Very Low \\
\hline
\end{tabular}

\section{Result and Discussion}

Figure 1 shows the acquisition of learning independence for prospective student teachers at Universitas Samawa. Based on the data in the figure, the scores obtained by students in the social and humanities fields were higher than in the exact fields. The difference in scores obtained between the two groups of fields is 2.08 .

Figure 2 shows students' scores on each indicator of learning independence. The data in the figure shows that students in the social and humanities fields scored higher than students in science on every indicator except for the discipline indicator. In the discipline indicator, students in the exact field were 0.55 higher than students in the social and humanities fields.

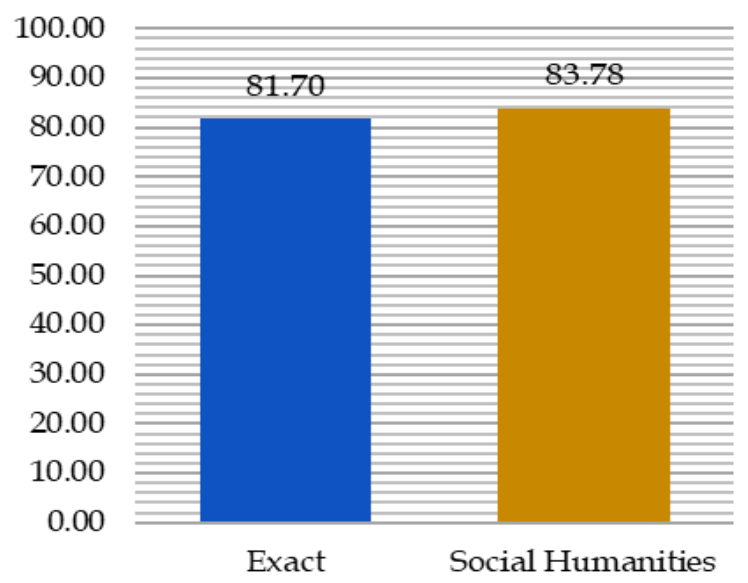

Figure 1. Learning Independence of Prospective Teacher Students

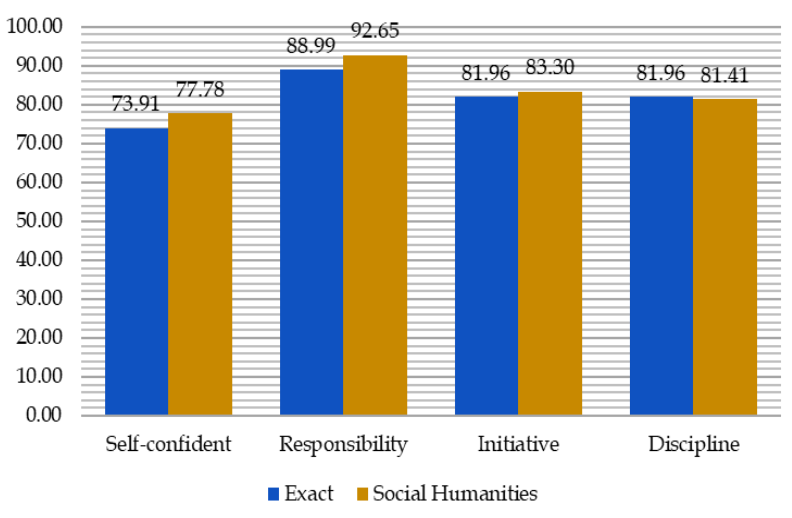

Figure 2. Learning Independence of Prospective Teacher Students on Each Indicator

In Table 1 it can be seen that the significance value of the comparison of student learning independence in the exact fields and social humanities is 0.140 . This shows that there is no significant difference between students in the exact sciences and social humanities.

The results of this study indicate that the value of student learning independence in the social humanities field is higher than students in the exact field. After testing the differences in learning independence, it turns out that there is no significant difference between the two fields of science. The absence of differences in learning independence between students in the exact fields and social humanities occurs because the treatment given to the two groups of fields tends to be the same, namely using e-learning. The similarity is found in the content and procedures for the treatment given.

Table 1. Results of Student Learning Independence Statistics Test for Prospective Teachers

\begin{tabular}{lll}
\hline No & Test & Learning Independence \\
\hline 1 & Mann-Whitney U & 374.000 \\
2 & Wilcoxon W & 674.000 \\
3 & Z & -1.475 \\
4 & Asymp. Sig. (2-tailed) & 0.140 \\
\hline
\end{tabular}


The absence of differences in learning independence in the two field groups also occurred because the scores obtained by the two field groups were not too different even though the social humanities group was higher than the exact field group. The high value of student learning independence in the social humanities group is due to the fact that based on the characteristics of the courses and the material being taught is more dominant in theory so that it does not require further explanation in the form of practicum or field problems solving. In contrast to the exact group of students, the material is more dominant on concepts that require further explanation, such as practical activities. Practical activities emphasize the level of student confidence, responsibility, and initiative.

Some practical or experimental activities cannot be explained through e-learning because the e-learning system does not support several applications that can be used to carry out practical activities. This causes the low level of learning independence of prospective teacher students, especially in the exact field group.

E-Learning is an example of technology in education that can support a conducive atmosphere in the teaching and learning process, especially during a pandemic like today. Students are required to study independently. Independent learning is one of the important goals in the learning process. This is in line with the Presidential Regulation of the Republic of Indonesia No. 87 of 2017 concerning strengthening character education which states that in order to create a cultured nation through strengthening religious values, honesty, tolerance, discipline, hard work, creativity, independence, democratic, curiosity, national spirit, love for the homeland, respect achievement, communicative, peace-loving, fond of reading, care for the environment, social care, and responsibility, need to strengthen character education (Huda et al., 2019).

Independent learning is a learning process where each individual has the initiative with or without the help of others, in terms of determining learning activities, such as determining learning objectives, learning resources, learning needs, learning strategies, and evaluating the learning process (Supriani, 2017). A student is said to have learning independence if he has his own desire to learn, solve problems, and is responsible for completing his obligations (Wahyuni \& Nurhayati, 2019).

The application of e-learning is a new medium that can overcome the passive attitude of students, increase enthusiasm for learning, allow direct interaction and allow students to learn independently (Nana \& Surahman, 2019). E-Learning is an internetbased electronic technology-based learning that is used to make it easier to receive knowledge and improve students' skills (Sagita \& Khairunnisa, 2019).

Learning independence is a process that can be improved, but requires habituation, a strong will because many are based on the internal factors of each individual, so it is not easy to be able to change it. (Supianti, 2016). In line with the results of research ( Hermansyah et al., 2020) learning independence is closely related to the level of discipline of prospective teachers, self-confidence, initiative, and responsibility for the assigned tasks also affect their learning independence.

Based on the results of research (Wilson, 2020) the E-learning learning system must be balanced with increasing the competence of lecturers. Students faced by lecturers today are millennial generation students who are technology literate, therefore lecturers are required to always improve scientific competence and innovate learning methods so that students can be more motivated and excited to carry out the learning process. This is in line with the opinion of Firdawati et al. (2021) which states that the use of technology in the teaching and learning process as an interactive medium can increase student motivation. Learning motivation is an encouragement to carry out the learning process. Students who have high motivation will have enthusiasm and energy to carry out daily learning activities. Meanwhile, from the student's perspective, what must be addressed is the readiness of students to learn independently. Since online learning is more likely to adopt the term self-directed learning, student self-study is important.

Online learning is effective for overcoming learning that allows lecturers and students to interact in virtual classrooms that can be accessed anywhere and anytime. Online learning can make students learn independently and increase their motivation. However, there is a weakness that students' online learning is not properly supervised during the online learning process. Weak internet signals and high quotas are a challenge for online learning (Sadikin \& Hamidah, 2020) In line with research (Indrayana \& Sadikin, 2020) that elearning can make students learn independently and dare to think and be active. However, the weaknesses of e-learning are internet signals in remote areas, limited quota, and difficulties in supervising students

Based on research (Sudiana et al., 2017) that in virtual classroom learning students are weak in targeting indicators and learning objectives compared to students who receive conventional learning. There are several reasons why learning in virtual classrooms has not contributed well to student learning independence, because learning independence is formed through a learning process obtained from childhood to adulthood. This intelligence is obtained 
after a person goes through a development that is very influential for the development of his independence. Learning independence has a dynamic nature, meaning that it does not escape change. There are indicators that can last for a certain period of time, but there are also those that can change according to momentary situations. This means that there is a possibility to increase or increase one's learning independence.

\section{Conclusion}

The learning independence of prospective students in the field of exact sciences is lower than that of prospective teachers in the social and humanities field. The learning independence of prospective teacher students can be influenced by the types of learning support devices such as e-learning with the types of courses or majors taken by students. E-learning currently cannot be used as a maximum supporting medium for prospective students in the exact field of science because in some concepts from exact material there are concepts that need to be explained directly by doing practicums that cannot be done using e-learning to its full potential.

\section{Acknowledgements}

Thank you to the five heads of study programs at the Faculty of Teacher Training and Education Universitas Samawa who have facilitated this research.

\section{References}

Ahmad, L. F., Danial, M., \& Gani, T. (2019). Pengaruh Model Pembelajaran Terhadap Kemandirian Belajar Dan Pemahaman Konsep Peserta Didik Kelas Xi Mia Sma Negeri 2 Gowa Tahun Ajaran 2017/2018 (Studi Materi Pokok Larutan Penyangga). Chemistry Education Review (CER), 2(2). $\quad$ https://doi.org/10.26858/cer.v2i2.8755 [Indonesian]

Ali, W. (2020). Online and Remote Learning in Higher Education Institutes: A Necessity in light of COVID-19 Pandemic. Higher Education Studies, 10(3). https://doi.org/10.5539/hes.v10n3p16

Amin, I., Yousaf, A., Walia, S., \& Bashir, M. (2021). What Shapes E-Learning Effectiveness among Tourism Education Students? An Empirical Assessment during COVID19. Journal of Hospitality, Leisure, Sport and Tourism Education. https://doi.org/10.1016/i.jhlste.2021.100337

Apriansyah, M. F., \& Pujiastuti, H. (2020). Pengembangan Bahan Ajar Matematika berbasis Virtual Learning dengan Gnomio. Jurnal
Pendidikan

Matematika, 11(2). https://doi.org/10.36709/jpm.v11i2.11921

[Indonesian]

Basilaia, G., \& Kvavadze, D. (2020). Transition to Online Education in Schools during a SARSCoV-2 Coronavirus (COVID-19) Pandemic in Georgia. Pedagogical Research, 5(4). https://doi.org/10.29333/pr/7937

Crawford, J., Henderson, K. B., Rudolph, J., Malkawi, B., Glowatz, M., Burton, R., Magni, P. A., \& Lam, S. (2020). Journal of Applied Learning \& Teaching COVID-19: 20 countries ' higher education intra-period digital pedagogy responses. Journal of Applied Learning \& Teaching, 3(1).

Fahmi, M. H. (2020). Komunikasi Synchronous Dan Asynchronous dalam E-Learning Pada Masa Pandemic Covid-19. Jurnal Nomosleca, 6(2). https://doi.org/10.26905/nomosleca.v6i2.4947 [Indonesian]

Febriastuti. (2013). Peningkatan Kemandirian Belajar Siswa SMP Negeri 2 Geyer Melalui Pembelajaran Inkuiri Berbasis Proyek. Unnes Physics Education Journal, 2(1). https://doi.org/10.15294/upej.v2i1.1617 [Indonesian]

Firdawati, R., Maison, M., \& Nazarudin, N. (2021). Development of Mobile Learning Media on Newton's Laws Using the Appy Pie Application. Jurnal Penelitian Pendidikan IPA, 7(2). https://doi.org/10.29303/ippipa.v7i2.599

Haryadi, R., \& Jannah, R. (2020). Pembelajaran Daring Fisika Pada Siswa Sekolah Menengah Atas ( SMA ). Edumaspul: Jurnal Pendidikan, 4(2), 355363.

https://doi.org/10.33487/edumaspul.v4i2.842 [Indonesian]

Hermansyah, H., Yahya, F., Fitriyanto, S., Musahrain, M., \& Nurhairunnisah, N. (2020). Kemandirian Belajar Calon Guru Fisika Melalui Pembelajaran Berbasis LMS: Schoology. Indonesian Journal of STEM Education, 2(1), 34-42. Retrieved from https://journal.publicationcenter.com/index.php/ijse/article/view/119 [Indonesian]

Hernawati, E., \& Aji, P. (2016). Perancangan dan Penerapan Konten e-Learning melalui Learning Management System dalam Meningkatkan Motivasi Belajar Studi Kasus pada Mata Kuliah Pemrograman Basis Data. Journal of Information Systems Engineering and Business Intelligence, 2(1). https://doi.org/10.20473/jisebi.2.1.23-32 [Indonesian]

Herwanto, H., Karnasih, I., \& Mujib, A. (2020). Pengaruh Pendekatan Pembelajaran Matematika 
Realistik (PMR) terhadap Kemampuan Pemahaman Konsep Matematis dan Kemandirian Belajar Siswa SMP. Edumaspul: Jurnal Pendidikan, 4(2), $72 \quad$ - 77. https://doi.org/10.33487/edumaspul.v4i2.679 [Indonesian]

Hodges, C., Moore, S., Lockee, B., Trust, T., \& Bond, A. (2020). The Difference Between Emergency Remote Teaching and Online Learning. Educause. http://hdl.handle.net/10919/104648

Huda, Mulyono, Rosyida, \& Wardono. (2019). Kemandirian Belajar Berbantuan Mobile Learning. PRISMA, Prosiding Seminar Nasional Matematika, 2, 798-806. Retrieved from https://journal.unnes.ac.id/sju/index.php/pris ma/article/view/29270 [Indonesian]

Indrayana, B., \& Sadikin, A. (2020). The Application of E-Learning in the Era of the Industrial Revolution 4.0 to Suppress the Spread of Covid19. Ijjssc, $0(1)$. https://doi.org/10.22437/ijssc.v2i1.9847

Kusmana, A. (2011). E-learning dalam Pembelajaran. Lentera Pendidikan: Jurnal Ilmu Tarbiyah dan Keguruan, 14(1), 35-51. https://doi.org/10.24252/lp.2011v14n1a3 [Indonesian]

Lestari, I., Andinny, Y., \& Mailizar, M. (2019). Pengaruh Model Pembelajaran Situation Based Learning dan Kemandirian Belajar Terhadap Kemampuan Pemecahan Masalah Matematis. JNPM (Jurnal Nasional Pendidikan Matematika), 3(1). https://doi.org/10.33603/jnpm.v3i1.1748 [Indonesian]

Mahdi, H., \& Sally., S. (2010). Developing and Implementing a Multi-Agent System for Collaborative E-learning. In E-learning. https://doi.org/10.5772/7788

Mukhlisa, R., Gani, A., Winarni, S., Khaldun, I., \& Hanum, L. (2021). Independence of Learning and Achievement of Learners' Cognitive Abilities in Thermochemical Materials through the Application of Flipped Classroom. Jurnal Penelitian Pendidikan IPA, 7(4), 523-530. https://doi.org/10.29303/ippipa.v7i4.674

Naidu, S. (2006). E-Learning A Guidebook of Principles, Procedures and Practices. In E-learning. http://hdl.handle.net/11599/53

Nana, N., \& Surahman, E. (2019). Pengembangan Inovasi Pembelajaran Digital Menggunakan Model Blended POE2WE di Era Revolusi Industri 4.0. Prosiding SNFA (Seminar Nasional Fisika Dan Aplikasinya), 4. https://doi.org/10.20961/prosidingsnfa.v4i0.359 15 [Indonesian]

Nasution, T. (2018). Membangun Kemandirian Siswa
Melalui Pendidikan Karakter. Ijtimaiyah: Jurnal Pendidikan dan Ilmu Sosial, 2(1). [Indonesian]

Riduwan. (2012). Belajar Mudah Penelitian untuk Guru, Karyawan, dan Peneliti Pemula. Bandung: Alfabeta. [Indonesian]

Rizal, S., \& Walidain, B. (2019). Pembuatan Media Pembelajaran E-Learning Berbasis Moodle Pada Matakuliah Pengantar Aplikasi Komputer Universitas Serambi Mekkah. Jurnal Ilmiah Didaktika: Media Ilmiah Pendidikan Dan Pengajaran, 19(2). $\quad$ https://doi.org/10.22373/jid.v19i2.5032 [Indonesian]

Sadikin, A., \& Hamidah, A. (2020). Pembelajaran Daring di Tengah Wabah Covid-19. BIODIK, 6(2). https://doi.org/10.22437/bio.v6i2.9759 [Indonesian]

Sagita, M., \& Khairunnisa. (2019). Pemanfaatan ELearning Bagi Para Pendidik Di Era Digital 4.0 Utilization Of E-Learning For Educators In Digital Era 4.0. Jurnal Sosial Humaniora, 2(2). https://doi.org/10.47647/jsh.v2i2.169 [Indonesian]

Sudiana, R., Fatah, A., \& Khaerunnisa, E. (2017). Kemandirian Belajar Mahasiswa Melalui Pembelajaran Berbasis Virtual Class. Jurnal Penelitian Dan Pembelajaran Matematika, 10(1). https://doi.org/10.30870/jppm.v10i1.1292 [Indonesian]

Sulistyohati, A. (2020). Pengukuran Elearning Readiness Pada Mahasiswa Sebagai Upaya Penerapan Pembelajaran Jarak Jauh Masa Pandemi COVID-19. Edumatic: Jurnal Pendidikan Informatika, 4(2), 136- 145. https://doi.org/10.29408/edumatic.v4 i2.2674 [Indonesian]

Sumarmo, U. (2010). Kemandirian Belajar. Bandung: Tarsito. [Indonesian]

Supianti, I. I. (2016). Dampak Penerapan E-Learning Dalam Pembelajaran Matematika Terhadap Kemandirian Belajar Mahasiswa. Teorema: Teori Dan Riset Matematika, 1(1). https://doi.org/10.25157/teorema.v1i1.119 [Indonesian]

Supriani, Y. (2017). Menumbuhkan Kemandirian Belajar Matematika Siswa Berbantuan Quipper School. JIPMat, $1(2)$. https://doi.org/10.26877/jipmat.v1i2.1248 [Indonesian]

Tarhini, A., Hone, K., Liu, X., \& Tarhini, T. (2017). Examining the Moderating Effect of IndividualLevel Cultural Values on Users' Acceptance of ELearning In Developing Countries: A Structural Equation Modeling of An Extended Technology Acceptance Model. Interactive Learning Environments, 25(3). 
https://doi.org/10.1080/10494820.2015.1122635

Tawafak, R. M., Romli, A. B. T., Arshah, R. bin A., \& Malik, S. I. (2020). Framework design of university communication model (UCOM) to enhance continuous intentions in teaching and elearning process. Education and Information Technologies, $25(2)$.

https://doi.org/10.1007/s10639-019-09984-2

Tigowati, T., Efendi, A., \& Budiyanto, C. W. (2017). ELearning Berbasis Schoology dan Edmodo: Ditinjau Dari Motivasi dan Hasil Belajar Siswa SMK. Elinvo (Electronics, Informatics, and Vocational Education), 2(1). https:// doi.org/10.21831/elinvo.v2i1.16416 [Indonesian]

W., Bao. (2020). COVID-19 and Online Teaching In Higher Education: A Case Study of Peking University. In Human Behavior and Emerging Technologies

(Vol.

2). https://doi.org/10.1002/hbe2.191

Wilson, A. (2020). Penerapan Metode Pembelajaran Daring (Online) melalui Aplikasi Berbasis Android saat Pandemi Global. SAP (Susunan Artikel Pendidikan), 5(1). https://doi.org/10.30998/sap.v5i1.6386 [Indonesian]

Wahyuni, R. \& Nurhayati, N. (2019) 'Kemandirian Belajar Mahasiswa Melalui Blended Learning Pada Mata Kuliah Matematika Ekonomi', AlQalasadi: Jurnal Ilmiah Pendidikan Matematika, $3(2)$, pp. 76-81. https://doi.org/10.32505/v3i2.1367 [Indonesian] Yulianci, S., Nurjumiati, N., Asriyadin, A., \& Adiansha, A. A. (2021). The Effect of Interactive Multimedia and Learning Styles on Students' Physics Creative Thinking Skills. Jurnal Penelitian Pendidikan IPA, 7(1). https://doi.org/10.29303/jppipa.v7i1.529 